Rehabilitation Research and Training Center for Economic Research on Employment Policy for Persons with Disabilities

Policy Brief

\title{
Program Expenditures for Working-age People with Disabilities in a Time of Fiscal Restraint
}

Nanette Goodman

David C. Stapleton

Cornell University Institute for Policy Research 
For further information about this paper contact:

Nanette Goodman

Cornell University Institute for Policy Research

1341 22nd Street, NW

Washington, DC 20037-3010

tel 202.223.7670

emailng54@cornell.edu

web www.human.cornell.edu/che/CUIPR/

This Policy Brief is being distributed by the Rehabilitation Research and Training Center for Economic Research on Employment Policy for Persons with Disabilities at Cornell University.

This center is funded to Cornell University, in collaboration with The Urban Institute (Washington, DC), by the U.S. Department of Education, National Institute on Disability and Rehabilitation Research (No. H133B980038). The contents of this paper do not necessarily represent the policy of the Department of Education, and you should not assume endorsement by the Federal Government (Edgar, 75.620 (b)). The views in this policy brief are not necessarily endorsed by Cornell University or the American Association of People with Disabilities.

\section{The Co-Principal Investigators are:}

Susanne M. Bruyère-Director, Employment and Disability Institute, School of Industrial and Labor Relations, Extension Division, Cornell University

Richard V. Burkhauser-Sarah Gibson Blanding Professor and Chair, Department of Policy Analysis and Management, College of Human Ecology, Cornell University

David C. Stapleton-Director, Cornell University Institute for Policy Research 


\section{Introduction}

Public expenditures in federal and federal-state programs for working-age people with disabilities totaled an estimated \$276 billion in 2002. The federal share of these expenditures, \$226 billion, was 11.3 percent of all federal outlays; states contributed an additional $\$ 50$ billion ${ }^{1}$. These expenditures accounted for about 2.7 percent of the nation's gross domestic product (GDP) ${ }^{2}$ and are growing much faster than GDP and all federal outlays. Most

expenditures were for income support and health care to people with disabilities who were not employed or who had very low earnings.

The fact that the relative economic well-being of working-age people with disabilities is falling has prompted increased scrutiny of how money is spent and whether there are any significant policy reforms that should be pursued (Stapleton and Burkhauser, 2003). This scrutiny will become more intense if the federal deficit rises, as it is projected to do, and the prevalence of disability grows as the baby boom generation ages.

These circumstances make it an opportune time to re-evaluate the structure of federal disability programs and whether they are properly aligned with the evolving disability paradigm - a paradigm that stresses helping people with disabilities help themselves to be full members of the economic and social lives of their communities, rather than objects of charity (Stapleton et. al, 2005).

\section{Types of Expenditures}

The two largest categories of expenditures --income security and health care--accounted for 96 percent of federal and federal-state expenditures for working-age people with disabilities. (Exhibit 1).

Exhibit 1: $\quad$ Federal and Federal-State Program Expenditures for Working-age People with Disabilities in Fiscal Year 2002, by Category of Expenditures

\begin{tabular}{lrr} 
Category & $\begin{array}{c}\text { Expenditures } \\
\text { (in \$ millions) }\end{array}$ & $\begin{array}{c}\text { Percent of } \\
\text { Total }\end{array}$ \\
\hline Income Maintenance & 115,507 & $41.9 \%$ \\
Health Care Programs & 149,590 & $54.2 \%$ \\
Housing and Food & 5,545 & $2.0 \%$ \\
Education, Training, and Employment & 4,092 & $1.5 \%$ \\
Other & 1,295 & $0.5 \%$ \\
\hline Total & 276,029 & $100.0 \%$ \\
\hline
\end{tabular}

1 We have not attempted a complete accounting of state and local expenditures for working-age people with disabilities under nonfederal programs, but they are substantial. For instance, they would include $\$ 12.4$ billion for mental health (Lutterman et al 2003), and $\$ 4.9$ billion for Mental Retardation and Developmental Disabilities (Rizzolo et al 2004).

2 Based on a GDP of $\$ 10.5$ trillion in 2002 reported by the Bureau of Economic Analysis. Available at http://www.bea.doc.gov/bea/dn/ gdplev.xls 
Eligibility for several of the large programs, most notably Medicare and Medicaid, is tied to eligibility for SSI or SSDI. Together, cash assistance and health care for the 8.7 million beneficiaries of these two programs totals $\$ 207$ billion, or $\$ 23,900$ per beneficiary.

\section{Policy Implications}

Much consideration is being given to disability policy reforms that would bring disability programs more in line with the goals of the Americans with Disabilities Act, the aspirations of people with disabilities, and advances in technology and medical care. In considering such reforms, it is critical to be aware of the size and distribution of current expenditures. Seventy-six percent of the \$276 billion of expenditures is for cash support and health care for working-age people who, according to the Social Security Administration, are unable to work. Total spending on cash assistance and health, including support for people with disabilities who are not in SSDI or SSI, accounts for 96.1 percent of the total. Relatively little is spent on programs that are designed to attain the goals embodied in the new policy paradigm; only 1.5 percent of funding is spent on education, training, and employment.

To promote independence and productivity, we could increase expenditures on programs that promote these goals, and leave others largely intact. This approach is unrealistic, however, because of current and projected federal deficits. The federal government ran a \$319 billion deficit in 2005 (Snow \& Bolton, 2005). Further, in the absence of major policy change, deficits are expected to grow rapidly in the future, driven partly by the entry of the baby boom generation into its retirement years (Walker, 2004). Thus, it is more realistic to expect real cuts in disability programs as deficit pressures increase. The sheer size of the major disability programs, along with the fact that program expenditures have been growing at a much faster rate than overall growth in federal expenditures, makes them particularly vulnerable to cuts. Over a decade and a half, federal expenditures on working-age people with disabilities have grown from 6.1 percent to 11.3 percent of federal outlays and from 1.4 percent to 2.2 percent of GDP. ${ }^{1}$ Such growth cannot be sustained indefinitely.

Realistically, policy reforms that promote independence are not likely to be adopted unless they reduce the rate of growth of government expenditures on disability programs to a sustainable rate. Given the current distribution of federal and state expenditures for this population, such policies would almost certainly have to reduce expenditures for cash assistance and health care.

There are compelling arguments for a host of incremental changes to reduce expenditures and promote independence. For example, expensive medical rehabilitation, residential programs, and long-term care could be reallocated to lower-cost personal assistance and support services; additional work incentives such as a benefit 
offset $^{1}$ could be added to SSDI to increase beneficiary earnings and reduce benefit costs; and greater investments could be made in the education, training, and retraining of people with disabilities. Incremental changes such as these, however, may neither substantially stem growth in public expenditures nor improve the lives of people with disabilities. A more fundamental restructuring of the disability support system may be necessary to achieve both objectives (Stapleton et al., 2005).

It is a formidable challenge to restructure these programs in a fiscally sustainable way that also does not substantially harm many of the people with significant disabilities who rely heavily on current programs. If reforms do not address this challenge, however, it seems likely that the economic and social well-being of working-age people with disabilities will continue to fall further behind that of the remainder of the workingage population.

For a description of the expenditures included in the calculations, contact Nanette Goodman at: ng54@,cornell.edu.

This policy brief is based on a paper by Goodman and Stapleton titled, "Federal Program Expenditures for Working-age People with Disabilities," forthcoming in the Journal of Disability Policy Studies.

1 A benefit offset would replace the abrupt loss of cash benefits in the SSDI program when a beneficiary earns over a specific amount with a gradual reduction in benefits. 


\section{References}

Berkowitz, M., \& Greene, C. (1989). Disability Expenditures. American Rehabilitation, Spring, 15(1), 7-15.

Lutterman, T., Hollen, V. \& Shaw, R. (2003). Funding Sources and Expenditures of State Mental Health Agencies: Fiscal Year 2001. National Association of State Mental Health Program Directors Research Institute, Inc. Retrieved November 24, 2004, from http://nri.rdmc.org/RevExp01/01REreport1.pdf

Rizzolo, M.C.,. Hemp, R. , Braddock, D. \& Pomeranz-Essley, A. (2004). The State of the States in Developmental Disabilities. Washington, DC: American Association on Mental Retardation. Retrieved December 14, 2004, from http://www.cu.edu/ColemanInstitute/stateofthestates/index.html.

Snow, J.W. \& Bolten, J.B. (2005, October 14). Joint Statement of John W. Snow, Secretary of the Treasury and Joshua B. Bolten, Director of the Office of Management and Budget, on Budget Results for Fiscal Year 2005. Washington DC: US Department of Treasury.

Stapleton, D., \& Burkhauser, R. C. (2003). Contrasting the Employment of Single Mothers and People with Disabilities. Upjohn Institute Employment Research Report, 10(3).

Stapleton, D. C., O’Day, B., Livermore, G. A., \& Imparato, A. J. (2005, July). Dismantling the Poverty Trap: Disability Policy for the 21st Century. Rehabilitation Research and Training Center for Economic Research on Employment Policy for Persons with Disabilities, Cornell University, Ithaca, NY. Retrieved October 24, 2005 from http://digitalcommons.ilr.cornell.edu/edicollect/124

Walker, D.M. (2004). Transforming SSA's Disability Programs for a 21 st Century America. Paper presented to the Social Security Advisory Board Forum on the Social Security Definition of Disability, Retrieved April 4, 2004, from http://www.ssab.gov/ DisabilityForum/DisabilityForum.htm 


\section{A selected listing of Cornell University Employment Policy RRTC publications}

Bruyère, S., Erickson, W., VanLooy, S., Sitaras, E., Cook, J., Burke, J., Farah, L., \& Morris, M. (2003). Employment and disability policy: Recommendations for a social sciences research agenda. In F. Menz \& D. Thomas (Eds.), Bridging Gaps: Refining the Disability Research Agenda for Rehabilitation and Social Sciences, Conference Proceedings. Menomonie, WI: University of Wisconsin-Stout, Stout Vocational Rehabilitation Institute, Research and Training Centers.

Bruyère, S., Patterson, J., \& Jenkins, W. (2005). Philosophical, historical, legislative, and professional aspects of the rehabilitation counseling profession. In R. Parker, E. Szymanski, \& J. Patterson, Rehabilitation Counseling: Basics and Beyond, (4th ed.), Austin, TX: Pro-Ed, Inc.

Bruyère, S., \& VanLooy, S. (2005). Legislation and rehabilitation service delivery. In M. Eisenberg, R Glueckauf, \& H. Zaretsky (Eds.), Medical Aspects of Disability: A Handbook for the Rehabilitation Professional (3rd ed., pp 827-850). New York: Springer Publishing.

Bruyère, S., VanLooy, S., \& Peterson, D. (2005). The International classification of functioning, disability and health (ICF): Contemporary literature overview. Rehabilitation Psychology. 50(2), 113-121.

Burkhauser, R., Butler, J., Feng, S., \& Houtenville, A. (2004) Long term trends in earnings inequality: What the CPS can tell us. Economics Letters. 82(2), 295-299.

Burkhauser, R., Butler, J., \& Gümüs G. (2004). Dynamic modeling of the SSDI application timing decision: The importance of policy variables, [Abstract]. Welfare State and Labor Market, Institute for Study of Labor (IZA), Discussion Paper No. 942.

Burkhauser, R., Butler, J., \& Gümüs G. (2004). Dynamic programming model estimates of Social Security Disability Insurance application timing. Journal of Applied Econometrics, 19, 671-685.

Burkhauser, R., \& Houtenville, A. (2003). Employment among working-age people with disabilities: What current data can tell us. In E. Szymanski \& R. Parker (Eds.), Work and Disability: Issues and Strategies for Career Development and Job Placement. (2nd ed.), Austin, TX: Pro-Ed, Inc.

Burkhauser, R., \& Stapleton D. (in press). Employing those not expected to work: The stunning changes in the employment of single mothers with children and people with disabilities in the United States in the 1990s., In B. Marin, C. Prinz \& M. Queisser (Eds.), Disability Policy Under Review, OECD.

Burkhauser, R., \& Stapleton, D. (Eds.) (2003). The Decline in Employment of People with Disabilities: A Policy Puzzle. Kalamazoo, MI: W.E. Upjohn Institute for Employment Research.

Burkhauser, R., \& Stapleton, D. (2004). The decline in the employment rate for people with disabilities: Bad data, bad health, or bad policy? Journal of Vocational Rehabilitation, 20(3), 185-201.

Horvath-Rose, A., Stapleton, D. \& O’Day, B. (2004). Trends in outcomes for young people with disabilities: Have policies aimed at social integration and economic independence been effective? Journal of Vocational Rehabilitation. 21(3), 175-187.

Houtenville, A. (2003). A comparison of the economic status of working-age persons with visual impairments and those of other groups. Journal of Visual Impairment and Blindness, 91(3), 133-148.

Houtenville, A. \& Burkhauser, R. (2005) Did the employment of people with disabilities decline in the 1990s, and was the ADA responsible: A replication and robustness check of Acemoglu and Angrist (2001). Ithaca, NY: Cornell University, Rehabilitation Research and Training Center for Economic Research on Employment Policy for People with Disabilities.

Stapleton, D. \& Tucker, A. (2000). Will expanding health care coverage for people with disabilities increase their employment and earnings? Evidence from an analysis of the SSI Work Incentive Program. In D. Salkever \& A. Sorkin (Eds.), Research in Human Capital and Development, 13, 133-180.

Wittenburg, D., Golden, T., \& Fishman, M. (2002). Transition options for youth with disabilities: An overview of the programs and policies that affect the transition from school. Journal of Vocational Rehabilitation, 17, 195-206.

Wittenburg, D. \& Maag, E. (2002). School to where? A literature review on economic outcomes of youth with disabilities. Journal of Vocational Rehabilitation, 17(4), 265-280.

For more information and a full listing of papers from the Employment Policy RRTC visit us on the web at: http://digitalcommons.ilr.cornell.edu/edi/. 
For more information about the Cornell RRTC contact:

Susanne M. Bruyère, Ph.D., CRC

Project Director

201 ILR Extension Building

Cornell University

Ithaca, NY 14853-3901

tel (607) 255-9536

fax (607) 255-2763

TDD (607) 255-2891

e-mailsmb23@cornell.edu

web www.ilr.cornell.edu/rrtc 